INOBIS: Jurnal Inovasi Bisnis dan Manajemen Indonesia

Volume 04, Nomor 01, Desember 2020

Nikolas F. Wuryaningrat, Aditya Pandowo, Lydia I. Kumajas

\title{
Persepsi Sosial Masyarakat Sulawesi Utara Di Saat Pandemi Covid-19
}

\author{
Nikolas F. Wuryaningrat* \\ Universitas Negeri Manado \\ Aditya Pandowo \\ Universitas Negeri Manado \\ Lydia I. Kumajas \\ Universitas Negeri Manado \\ *nikolas.fajar@unima.ac.id
}

\begin{abstract}
Abstrak
Tujuan penelitian ini untuk mengeksplorasi persepsi masyarakat atas pandemic Covid-19 dan dampak yang terjadi. Fenomena panic buying dan consumer hoarding turut dielaborasi sebagai titik akhir pandemic Covid-19. Sebanyak 220 responden dijadikan obyek penelitian dengan teknik pengambilan sampel menggunakan metode convenience sampling. Kuesioner disebarkan secara daring dengan menggunakan aplikasi survey monkey kepada calon responden diseluruh propinsi Sulawesi Utara. Hasil penelitian dari 220 respondenmenunjukkan kecemasan dan kekhawatiran akan ketidakpastian merupakan penyebab terjadinya fenomena panic buying dan consumer hoarding. Meski demikian, responden tetap optimis dapat melanjutkan aktivitas rutin pada saat pandemic Covid-19 berakhir karena tingginya kepercayaan kepada pemerintah, baik pusat maupun daerah. Selain itu, pandemic Covid-19 memberikan efek positif (peduli dengan kesehatan) dan negative terhentinya aktivitas luar rumah di masyarakat.
\end{abstract}

Kata kunci: covid-19, persepsi social masyarakat, panic buying

\section{Pendahuluan}

Saat ini sudah lebih dari 200 negara di seluruh dunia mengalami wabah virus corona Covid-19. Dengan meluasnya wabah covid-19 maka tidak mengherankan pada akhirnya World Health Organization (WHO) akhirnya menetapkan penyebaran virus Covid-19 sebagai pandemic global. Salah satu Negara yang terdampak adalah Indonesia, semenjak diumumkan pertama kalinya kasus Covid-19 pada awal bulan Maret 2020 oleh Presiden, pada akhir bulan Maretsudah menjangkiti1528 kasus positif Covid-19 dengan tingkat kematian yang masih lebih tinggi daripada tingkat kesembuhannya (Kompas.com, 31/3/2020; www.covid-19.go.id). Seperti negara lain didunia, masalah kesehatan pandemic global ini ikut menyeret ke isu ekonomi, sebagai contoh cnbc Indonesia pada tanggal 1 Mei 2020 melansir berita bahwa ekonomi Negara G-20 luluh lantak akibat corona.

Kebijakan pembatasan jarak fisik (physical distancing), penutupan sementara sekolah dan universitas, pelarangan sementara ibadah di tempat ibadah (Gereja, mesjid dll), pelarangan berkumpul dalam jumlah besar, himbauan tidak keluar kota dan luar negeri dan berbagai kebijakan lainnya memaksa roda ekonomi berjalan sangat lambat bahkan lang sung berhenti. Salah satu contoh bisnis di industry MICE (meeting, incentives, conferencing and exhibitions) sangat terpukul karena pandemic ini, Kementerian Pariwisata dan Ekonomi Kreatif seperti dilansir oleh Kompas (20/02/2020) menjelaskan banyak kegiatan-kegiatan event dibatalkan 
atau harus dijadwalkan kembali. Padahal dari industry MICE saja bisnis perjalanan wisata, transportasi umum/online, rumah makan, dan hotel langsung kena imbasnya dengan penurunan omzetnya mencapai lebih dari 70\% (Rapat kerja Kemenparkeraf dan DPR, 6 April 2020).Craven et al., (2020) menjelaskan bahwa pandemic covid-19 sudah membuat krisis pada banyak bisnis di seluruh dunia, yang mengancam pada krisis ekonomi.

Di masyarakat merebaknya virus covid-19 membuat potensi panic buying semakin tinggi, apalagi ditambah maraknya berita palsu (hoax) di media sosial membuat masyarakat seperti panic. Di Sulawesi Utara seperti diberitakan oleh Media Tribun Manado dan Manado Post (23 Maret 2020) masker, hand sanitizer, dan suplemen vitamin C dan E seakan lenyap di apotek dan malah lebih banyak beredar di tempat yang tidak resmi dan sulit dipastikan keasliannya dengan harga yang lebih mahal dari seharusnya. Pernyataan tersebut turut diamini oleh hasil survei social demografi BPS (2020) menjelaskan bahwa alat kesehatan, obat, vitamin dan sanitasi pada umumnya harganya naik.

Pola konsumtif masyarakat dibarang kebutuhan pokok juga terindikasi semakin tinggi karena masyarakat berbelanja dalam jumlah seperti tidak biasanya, konsumsi pembelian kuota internet semakin tinggi padahal tingkat pendapatan masyarakat secara umum semakin turun (BPS, 2020). Dengan kata lain, dapat dikatakan masalah virus covid-19 yang pada mulanya hanya berkaitan pada isu kesehatan sudah berkembang ke isu ekonomi, bahkan Menteri Keuangan Sri Mulyani pada sesi rapat dengan DPR di bulan Maret 2020, isu kesehatan akibat Covid-19 sudah mulai memicu kearah krisis ekonomi. Penurunan nilai rupiah ke 16 ribuan pada bulan Maret secara cepat dari sebelum hanya berkisar di 13 ribuan sampai 14 ribuan rupiah walaupun memasuki bulan April pergerakannya sudah cenderung stabil diangka Rp. 15,900an per dollar Amerika (bi.go.id; 9 April 2020). Masalah ekonomi lainnya adalah pemutusan hubungan kerja atau kebijakan dirumahkan karyawaan yang mengakibatkan pendapatan menurun adalah contoh akibat isu ekonomi yang ditimbulkan dari covid-19.

Dalam menghadapi pandemic covid-19, sikap masyarakat seperti terbelah, sebagian masyarakat menghendaki kebijakan lockdown (karantina wilayah) seperti yang diterapkan banyak negara lain (e.g. Perancis, Spanyol dll). Sebagian masyarakat tidak menghendaki hal tersebut dikarenakan matinya roda ekonomi. Pada akhirnya pemerintah mengambil opsi tidak memberlakukan kebijakan karantina wilayah, kebijakan pembatasan sosial berskala besar (PSBB) dipilih seperti tertuang pada Peraturan Pemerintah nomor 21 tahun 2020.Seperti pengamatan dari berbagai media televisi dan online yang kredibel (Kompas, CNN Indonesia, detikcom) kebijakan PSBB banyak yang meragukan dapat memutus mata rantai penyebaran virus Covid-19. Salah satunya Epidemiolog FKM UI Pandu Riono seharusnya menyebut PSBBdiberlakukan secara nasional bukan per daerah sesuai pengajuan dari Pemerintah daerah (news.detik.com; 1 Mei 2020).Dengan demikian perlu mengetahui persepsi masyarakat akan kepercayaannya pada Pemerintah pusat dan daerah.

Riset ini dilakukan untuk menilai persepsi masyarakat khususnya di Sulawesi Utara. Provinsi Sulawesi Utara merupakan salah Provinsi di Indonesia yang tingkat pertumbuhan ekonominya cukup tinggi yang tidak lepas pula dari masalah pandemic covid-19 ini dengan menurunnya tingkat wisatawan local dan macanegara, serta pendapatan yang cenderung turun (sulut.bps.go.id/1 April 2020). Riset ini dilakukan untuk mengukur persepsi masyarakat saat pandemic ini berlangsung dan mengukur persepsi masyarakat aktivitas panic buying, apa yang akan dikerjakan saat pandemic sudah berakhir, serta sikapnya terhadap pemerintah pusat dan daerah. 
INOBIS: Jurnal Inovasi Bisnis dan Manajemen Indonesia Volume 04, Nomor 01, Desember 2020

Nikolas F. Wuryaningrat, Aditya Pandowo, Lydia I. Kumajas

\section{Landasan Teori}

\section{Persepsi sosial masyarakat}

Sebagai makhluk hidup yang mampu beradaptasi dengan kelompok dan pola social yang kompleks, maka dipandang perlu untuk memahami perilaku individu sebagai bagian interaksi dan komunikasi antar manusia. Tindakan dan perilaku manusia salah satunya didasari atas persepsi yang terbentuk oleh system pengamatan (Knoblich \& Prinz, 2001). Tindakan dan perilaku individu yang terbentuk dari persepsi disebabkan dua hal (Passer \& Smith, 2009): pertama, disposisi pribadi, yaitu perilaku yang terkait dengan karakterisitik internal seperti, kepribadian, kepercayaan, dan sikap. Kedua, disposisi situasional, yaitu perilaku yang disebabkan karena situasi yang terjadi diluar kehendak pribadi dan dipengaruhi aspek eksternal lingkungan.

Persepsi social itu sendiri didefinisikan sebagai tahap awal evaluasi niat dan disposisi psikologis orang lain dengan analisis perspektif, isyarat tubuh, dan gerakan lainya (Allison et al., 2000). Persepsi social mengacu pada identifikasi dan memanfaatkan isyarat social untuk membuat penilaian tentang peran social, aturan, hubungan, konteks, atau karaktersitik orang lain. Dengan kata lain, persepsi social mengukur pemahaman hubungan komunikasi social antar individu. Pendapat lainnya dikemukakan oleh (Baron \& Branscombe, 2012) sebagai suatu proses yang digunakan untuk mencoba memahami orang lain. Berdasarkan ketiga pendapat tersebut, persepsi social berarti suatu usaha untuk memahami orang lain dengan menggunakan komunikasi non verbal dan mengintepretasikannya sebagai bagian dari perilaku social dan perspektif sosial.

Beberapa factor diketahui turut mendukung terciptanya persepsi social seseorang (Hanurawan, 2007), seperti factor penerima, factor situasi, factor organisasi perspektual, dan factor obyek sasaran. Factor penerima bergantung pada karaktersitik pengamat berdasarkan konsep diri, nilai, sikap, pengalaman masa lalu, dan ekspektasi dalam dirinya. Factor situasi adalah factor pendorong yang berasal dari eksternal pengamat seperti seleksi, kesamaan, dan organisasi. Sementara itu, organisasi perspektual menuntut obyek sebagai sistem yang bersifat logis, teratur, dan runtut. Factor obyek sasaran adalah individu yang dijadikan sebagai obyek pengamatan dengan ciri-ciri khusus, unik, kontras, dan intensitas dalam obyek.

\section{Perilaku Panic Buying}

Istilah panic buying atau sering disebut juga consumer hoarding segera menjadi trending saat pandemic Covid-19 berlangsung. Panic buying merujuk pada tindakan seseorang untuk membeli dalam jumlah besar untuk menghindari kekurangan dimasa depan. Fenomena ini bisa tergambar dengan jelas dengan melihat beberapa indicator seperti, antrian panjang di pusat perbelanjaan, pembelian dalam jumlah besar, dan hilangnya persediaan dipasar yang menyebabkan munculnya kecemasan bagi khalayak ramai. Meski demikian, perilaku ini tidak selalu didorng karena factor emosi semata, tetapi sebagai respon atas ancaman ketersediaan dimasa depan dan hilangnya akses untuk mendapatkan sesuatu

Panic buying dapat terjadi dimana saja dan kapan saja. Pemicu panic buying sebagian besar disebabkan force majeure yang tidak dapat diantisipasi sebelumnya seperti: bencana alam, ketakutan akan kekurangan persediaan, serangan teroris, termasuk juga ancaman pemogokan besar-besaran (Fang \& Shou, 2015; Kumar et al., 2018). Meski demikian, alasan sesungguhnya dari perilaku ini adalah perasaan emosional akan kecemasan dan ketidakpastian dimasa depan. Kedua kondisi psikologis ini berhubungan dengan ketidakpercayaan masyarakat 
atas ketersediaan barang dan kenaikan harga barang yang signifikan.Beberapa akibat yang muncul karena adanya perilaku pembelian panik adalah:Terganggunya pasokan dan permintaan, ketersediaan barang dan kelangkaan dipasar, keputusan pengecer yang dapat mengganggu pola pembelian seperti: kenaikan harga, membatasi penjualan (quota), dan membatasi pasokan, dan fenomena penimbunan barang

Memahami perilaku pembelian dalam kepanikan mengandung tiga unsur: pertama, kepanikan terjadi karena adanya persepsi individu mengenai sinyal bahaya, ketidakmampuan dan kekhawatiran atas situasi yang mengancam, dan potensi ketiadaan solusi. Kombinasi dari ketiga hal tersebut mendorong kondisi panic seseorang. Kedua, usaha untuk menarik diri dari situasi yang mengancam merupakan hasil dari kepanikan seseorang. Ketiga, adanya perubahan perilaku akibat pengambilan keputusan individu untuk melepaskan diri dari kondisi panic

\section{Metode Penelitian}

\section{Partisipan Desain dan Prosedur}

Riset ini dilakukan dengan metode penelitian kuantitatif deskriptif. Survei online dipilih menggunakan aplikasi survey monkey agar penyebaran datanya lebih luas ke berbagai daerah di Sulawesi Utara.Dalam penelitian jumlah responden yang berpartisipasi selama kurang lebih 1 bulan pengumpulan data sebanyak 220 responden. Metode sampel dalam penelitian ini adalah sampel tidak acak dengan metode convinience. Metode sampel ini dipilih dikarenakan metode yang realistis untuk mendapatkan respon yang cepat. Kuesioner dikirimkan dengan aplikasi survei online SurveyMonkey, link dari aplikasi dikirimkan kepada grup whatsapp dari penulis dan jaringan pribadi whatsapp dan pesan teks (SMS) dari kontak penulis. Selain itu link juga dikirimkan via beranda Facebook peneliti/penulis. Data yang terkumpul kemudian dianalisa melalui aplikasi yang sama untuk mendapatkan data yang sudah terkumpul secara deskriptif.

Statistic deskriptif hanya digunakan untuk mengukur dataset tertentu saja, sehingga hasil riset ini tidak bisa digunakan untuk mengeneralisasi hasil ke populasi di Provinsi Sulawesi Utara yang mencapai angka lebih dari 2,5 juta penduduk (sulut.bps.go.id; 1 April 2020).Dengan kata lain hasil ini hanya bisa menangkap informasi dari 220 responden yang terjaring. Untuk menguatkan hasil penelitian, setelah data diperoleh dari 220 responden, dilakukan wawancara via chating dengan media whatsapp kebeberapa informan yang dianggap mampu memberikan informasi yang valid.

\section{Instrumen dan Teknik analisis}

Instrument penelitian ini terdiri dari 10 pertanyaan. Instrument ini terdiri dari 3 pertanyaam umum responden seperti usia, tempat tinggal dan domisili. Kemudian 7 pertanyaan merupakan kumpulan pernyataan persepsi responden yang terdiri dari aktivitas panic buying, perasaan yang dirasakan saat pandemic, rencana kedepan setelah pandemic berakhir, persepsi tentang kemampuan penanganan pandemic oleh Pemerintah pusat dan daerah. Selain itu kuesioner juga meliputi pernyataan tertulis responden mengenai pengetahuannya mengenai dampak positif dan negative dari pandemic Covid-19. Menguatkan informasi, seluruh item pernyataan ditambahkan kolom pernyataan yang bisa dijawab responden secara tulisan mengenai perasaan sebenarnya yang dirasakan.

Penelitian ini berlangsung dari minggu kedua maret sampai dengan minggu ketiga April 2020. Dikarenakan terbatasnya waktu riset dan untuk memastikan dapat mengkaji hasil yang 
masih hangat serta sesuai dengan situasi saat ini maka survey online dengan menggunakan aplikasi Survey Monkey digunakan. Aplikasi ini sangat cocok untuk riset deskriptif karena selain membantu menyebar kuesioner online juga bisa menganalisa data tersebut.

Tabel 1. Demografi Responden

\begin{tabular}{llcc}
\hline \multirow{3}{*}{ Usia } & Demografis & Jumlah & Prosentase \\
& $17-24$ & 114 & 51.818 \\
& $25-34$ & 34 & 15.455 \\
\multirow{3}{*}{ Tempat tinggal } & $35-44$ & 38 & 17.273 \\
& 45 ke atas & 34 & 15.455 \\
Domisili & Kota & 83 & 37.277 \\
& Desa & 96 & 43.636 \\
& Pinggiran & 41 & 18.636 \\
& Manado & 20 & 9.091 \\
& Tomohon & 27 & 12.273 \\
& Kotamobagu & 19 & 8.636 \\
& Minahasa & 51 & 23.182 \\
& Minahasa Selatan & 29 & 13.182 \\
& Minahasa Tenggara & 21 & 9.545 \\
& Bolmong Raya & 18 & 8.182 \\
& Sangihe, Talaud, Sitaro & 15 & 6.818 \\
& Daerah Lainnya & & \\
& & 20 & 9.091 \\
\hline
\end{tabular}

Berdasarkan tabel 1, sebaran data responden meliputi usia, tempat tinggal, dan wilayah domsili. Responden terbanyak berasal dari rentang usia muda 17-24 tahun sebanyak 114 responden atau 51.818\%. Diikuti oleh rentang usia 25-34 tahun sebanyak 34, atau $17.273 \%$, dan rentang usia 35-44 tahun sebesar 38 responden atau $15.455 \%$. Sementara itu, rentang usia 45 tahun keatas sebanyak 34 responden atau $15.455 \%$. Dengan kata lain sebagian besar responden merupakan responden pada usia sekolah dan atau masih kuliah.

Untuk tempat tinggal responden, sebagian besar tinggal di desa sebanyak 96 responden atau $43.636 \%$. untuk responden yang tinggal di perkotaan sebesar 83 responden atau sebesar $37.277 \%$ dan sisanya tinggal di daerah pingiran antara kota dan desa sebanyak 41 responden atau memiliki porsi sebesar $18.636 \%$.

Pada area domisili berdasarkan wilayah administrasi di Provinsi Sulawesi Utara, responden terbesar berasal dari Kabupaten Minahasa sebesar 51 responden (23.182\%), dan diikuti oleh daerah lainnya Kabupaten Minahasa Selatan sebanyak 29 responden (13.182\%), kota Tomohon sebesar 27 responden (12.273\%), Kabupaten Minahasa Tenggara 21 orang (9.545\%), Kota Kotamobagu sebanyak 19 responden (8.636\%), seluruh Kabupaten di Bolaang Mongondow Raya (Bolmong) sebanyak 18 orang (8.182\%) dan terakhir adalah gabungan antara Kabupaten Sangihe, Talaud dan Sitaro sebanyak 15 responden (6.818\%). Adapun untuk daerah lainnya di luar Sulawesi Utara terkumpul 20 responden (9.091\%), dimana sebagian besarnya daerah yang banyak disebutkan adalah Provinsi DKI Jakarta, dan Jabodetabek,. Penelitian ini memang lebih dikhususkan untuk daerah Sulawesi Utara, daerah lainnya digunakan untuk pembanding saja. 
INOBIS: Jurnal Inovasi Bisnis dan Manajemen Indonesia Volume 04, Nomor 01, Desember 2020

Nikolas F. Wuryaningrat, Aditya Pandowo, Lydia I. Kumajas

\section{Hasil Penelitian dan Diskusi}

Sebanyak 220 orang responden berpartisipasi dalam penelitian ini dengan berbagai latar belakang usia, domisili, wilayah pemukiman, dan persepsinya mengacu pada pernyataannya.

\section{Aktivitas Panic Buying}

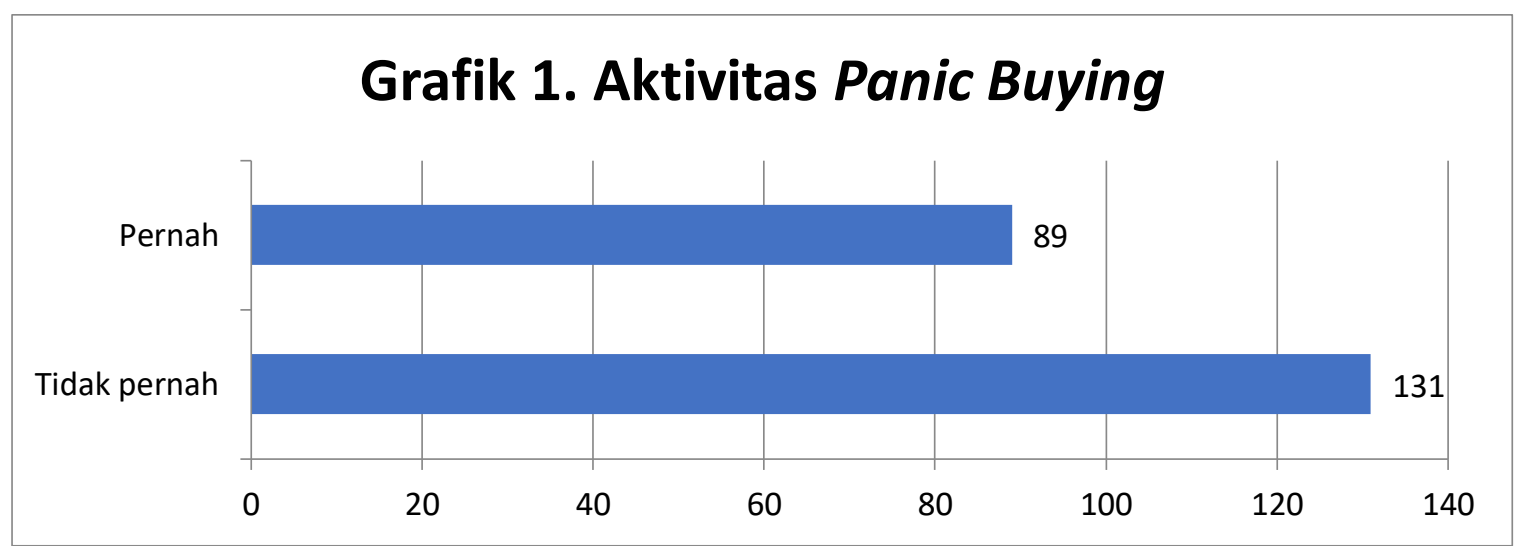

Pada grafik 1. ditunjukkan bahwa responden pada kurun waktu penelitian atau pada saat pandemic covid-19 mulai berkembang pesat di Indonesia sebagian besar (131 responden) tidak pernah atau belum pernah melakukan panic buying barang dan kebutuhan pokok. Dengan demikian 131 responden tersebut diindikasikan masih melakukan pembelian barang kebutuhan pokok secara normal dan rasional. Akan tetapi tidak sedikit juga responden (89 orang) sudah pernah melakukan pembelian yang berlebihan atau lebih banyak dari biasanya dengan alasan untuk mengantisipasi pandemic covid-19.

Kebijakan Pemerintah physical distancing dan merumah belajarkan anak sekolah dan mahasiswa untuk antisipasi penyebaran virus Covid-19 yang sangat cepat. Kebijakan ini memaksa keluarga untuk lebih banyak tinggal di dalam rumah dan hanya melakukan kegiatan luar rumah (e.g. bekerja) yang sangat penting saja. Dengan demikian, tidak mengherankan ketika banyak para orangtua/keluarga melakukan pembelian yang lebih banyak dari biasanya (Baker et al., 2020), tetapi informasi dari 220 data yang terkumpul pembelian yang dilakukan masih dalam jumlah yang normal dan rasional.

Dalam jawaban pernyataan dari responden yang ditulisnya secara bebas sesuai dengan perasaan yang dirasakannya mengenai aktivitas panic buying dapat beberapa responden yang sudah berkeluarga menjelaskan bahwa sebenarnya pembelian yang dilakukannya masih normal, tetapi terlihat banyak dikarenakan yang biasanya berbelanja satu minggu sekali, kini belanja langsung untuk kebutuhan 3 sampai 4 minggu. Dengan kata lain, nominal uang yang dibelanjakan relative sama saja, tetapi kuantitas waktu berbelanja kebutuhan yang berkurang.

Sebanyak 89 orang responden mengaku melakukan aktivitas panic buying melakukan pembelian yang lebih besar dari jumlah yang seharusnya dibeli.Sebagai contoh jika dalam satu bulan hanya memerlukan 10 kilogram beras, karena sikap paniknya maka akan membeli beras 20-30 kilogram beras untuk satu bulan.Salah seorang informan seorang wanita karir yang merupakan kenalan dari peneliti, menjelaskan dia dalam 1 bulan terakhir sudah mengeluarkan uang untuk berbelanja kebutuhan rumah tangga, anak-anak dan kuota internet sudah lebih besar dari pengeluaran bulanan biasanya. 
Sangat dimungkinkan perilaku dari 89 orang inilah yang mengindikasikan alasan dibalik beberapa produk seperti sabun cuci tangan, hand sanitizer, masker dan vitamin $\mathrm{C}$ menjadi langka dipasar serta memicu beberapa harga produk menjadi naik. Artinya walaupun masyarakat yang melakukan aktivitas panic buying jumlahnya hanya sebagian kecil dari yang tidak melakukannya, akan tetapi tampak memberikan dampak negative pada kelangkaan dan naiknya harga beberapa barang komoditas sangat tinggi. Sebagai contoh jika 89 orang saja melakukan pembelian beras secara berlebihan, misalnya 20 kilogram (kebutuhan sebenarnya $10 \mathrm{~kg}$ ) maka konsumsi beras menjadi 1780 kilogram, dengan kata lain perilaku 89 orang ini bisa saja membuat harga beras lebih naik karena permintaan yang lebih besar. Salah satu responden menjelaskan dia pernah membeli produk vitamin $\mathrm{C}$ yang harga pasarannya 40ribuan rupiah 10 pak (cth: 1 pak isi 30 tablet), dengan kata lain kalo saja 1 keluarga hanya butuh 1 sd 2 pak, maka 8 pak sisa itu mungkin bisa dianggap penimbunan. Wawancara via chatting whatsapp dengan salah satu area sales manajer salah satu perusahaan farmasi yang menjual produk multivitamin, mengatakan di Pulau Jawa saja produk merek 'E' sudah sulit dicari. Dengan demikian, jika jika pengakuannya benar maka jika di Pulau Jawa tempat produk tersebut diproduksi saja sudah sulit dicari apalagi di Sulawesi Utara (Indonesia Timur).

Sesi wawancara dengan supervisor supermarket besar di Kota Tomohon via chating whatsapp menjelaskan jika supermarket ini mendapat stok hand sanitizer, tidak sampai 2 jam stok tersebut habis. Kemudian dijelaskan kembali, sabun cuci tangan antiseptic sangat laku, stok yang ada hanya setengah hari saja sudah habis, padahal stok yang disediakan disituasi normal cukup untuk 2 minggu, dan mudah mendapatkannya dari penyalur. Dengan demikian, diduga dari perilaku panic buying 89 orang responden turut membuat kelangkaan tersebut.

Alasan lainnya, kenapa jumlah aktivitas panic buying lebih rendah dari yang belum pernah melakukan aktivitas panic buying dikarenakan berdasarkan data yang dihimpun sebagian besar responden dalam riset ini berusia relative muda antara 17-24 tahun (lihat tabel 1). Diusia yang relative muda inilah ada kemungkinan banyak yang masih menjadi tanggungan orang tua, sehingga belum terlalu merasakan atau belum menjadi actor panic buying. Segala macam kebutuhan masih ditanggung orang tua, sehingga belum berpengalaman untuk memenuhi kebutuhan hidupnya sendiri. Dengan demikian jika saja responden dalam riset in kebanyakan diusia orang tua, hasilnya mungkin akan berbeda.

Data dalam penelitian ini juga menunjukkan bahwa sebagian besar responden banyak tinggal di desa (tabel 1). Pemenuhan kebutuhan hidup di desa relatif lebih mudah jika dibandingkan dengan pemenuhan kebutuhan hidup di kota (Wuryaningrat, 2017). Di desa, khususnya di desa di Sulawesi Utara kebutuhan akan beras dan lauk pauk relatif bisa dipenuhi didesa itu sendiri. Masih banyak petani dan nelayan di desa yang bisa menanam padi, berternak dan menangkap ikan untuk digunakan bagi kebutuhan keluarganya sendiri(Lihat Mundayat et al., 2008). Dibandingkan di Kota, untuk bisa memenuhi kebutuhannya manusia harus bekerja. Pada saat pandemic covid-19 banyak karyawan terpaksa dirumahkan dengan tidak dibayar atau dibayar sebagian (pengamatan media) sehingga sulit bagi mereka memenuhi kebutuhannya. Maka tidak mengherankan gelombang masyarakat yang dulunya bekerja di Kota terpaksa mudik ke kampung halamannya, dikarenakan hilangnya mata pencahariannya. Alasan inilah yang mungkin diambil oleh Pemerintah yang belum melarang masyarakat untuk mudik, pemerintah hanya menghimbau agar masyarakat tidak pulang ke kampung halamannya. Walaupun belakangan pemerintah mengambil kebijakan untuk melarang mudik yang dimulai pada tanggal 24 April 2020. 


\section{Grafik 2. Perasaan Responden di Saat Pandemi Covid-19}

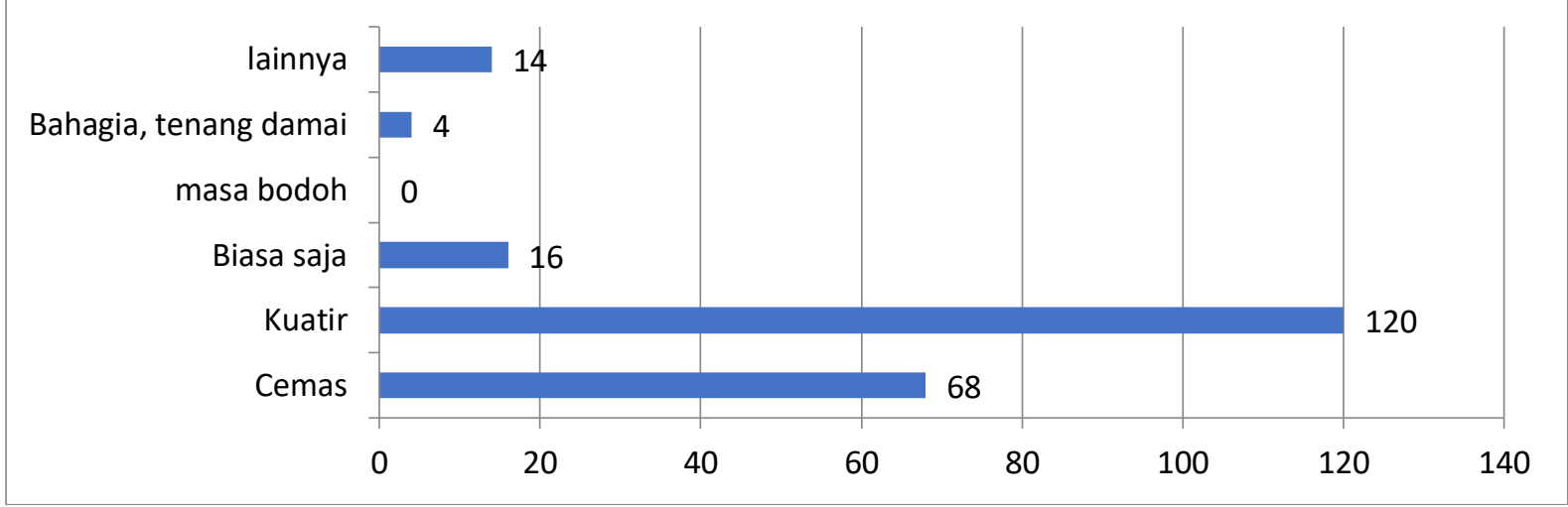

Pada grafik 2 ditunjukkan bahwa perasaan yang dirasakan oleh responden saat pandemic Covid-19 sebagian besar adalah rasa kuatir dan cemas, Hanya sebagian kecil respnden yang menganggap pandemic covid-19 merupakan hal yang biasa saja. Pada jawaban lainnya, sebagian besar dari 14 responden menuliskan bosan, yang berarti pandemic Covid-19 membuat sebagian responden menjadi bosan tinggal dirumah.

Perasaan kuatir dan cemas menjadi hal yang akan terjadi saat situasi pandemic apapun, termasuk pandemic covid-19. Semakin banyak dan cepatnya virus covid-19 terus menjangkiti masyarakat Indonesia dan dunia tentu saja membuat perasaan manusia menjadi lebih kuatir dan tidak merasa bebas berjalan kemana, karena takut tertular. Saat ini seseorang yang bersin atau batuk seakan-akan membuat masyarakat bersikap paranoid dan mencurigai berlebihan, padahal seperti yang kita ketahui bersama sebelum virus covid-19 ada bersin, batuk dan pilek tidak menjadi persoalan besar dalam masyarakat dan menjadi bagian dari hidup kita seharihari. Saat ini tampaknya sudah terjadi dimana buang angin (mohon maaf) menjadi lebih 'bermatabat' daripada flu dan batuk, demikian jawaban di sesi wawancara dengan salah satu rekan kerja peneliti.

Bagi sebagian masyarakat yang bekerja di sektor informal, kesulitan mendapatkan pendapatan menambah perasaan kuatir dan cemas bisa saja bertambah besar. Kekuatiran dan kecemasan tidak mampu membayar hutang/kredit, bayar kontrakan, bayar listrik dll menjadi contoh nyata yang saat ini terjadi. Sebenarnya cemas dan kuatir merupakan respon dari manusia dari situasi yang mengancam yang menjadi bagian dari hidup manusia sehari hari (Kaplan et al., 2007). Akan tetapi kuatir dan cemas karena factor sosial yang berlebihan akan menimbulkan stress dan menjadi ancaman bagi kesehatan manusia (Az-Zahrani, 2005). Dalam situasi pandemic covid-19 merupakan pengaruh dari factor sosial, menambah kecemasan dan kekuatiran hidup manusia, dan sangat memungkinkan stress bisa muncul dan mengurangi daya tahan tubuh seseorang. Seperti sudah dijelasakan oleh berbagai media bahwa daya tahan tubuh menjadi factor penting untuk mencegah penularan virus covid-19, jika daya tahan tubuh menurun maka virus mudah menyerang dan menimbulkan masalah kesehatan yang serius (WHO, 2020). Dengan demikian factor kuatir dan cemas karena covid-19 yang jika berlanjut lebih lama, memungkinkan penurunan imun sehingga penyebaran covid-19 semakin massif. Pernyataan diatas diamini oleh salah satu dokter yang diwawancarai via chat di whatsapp. 


\section{Keinginan Kedepannya setelah pandemic Covid-19 berakhir}

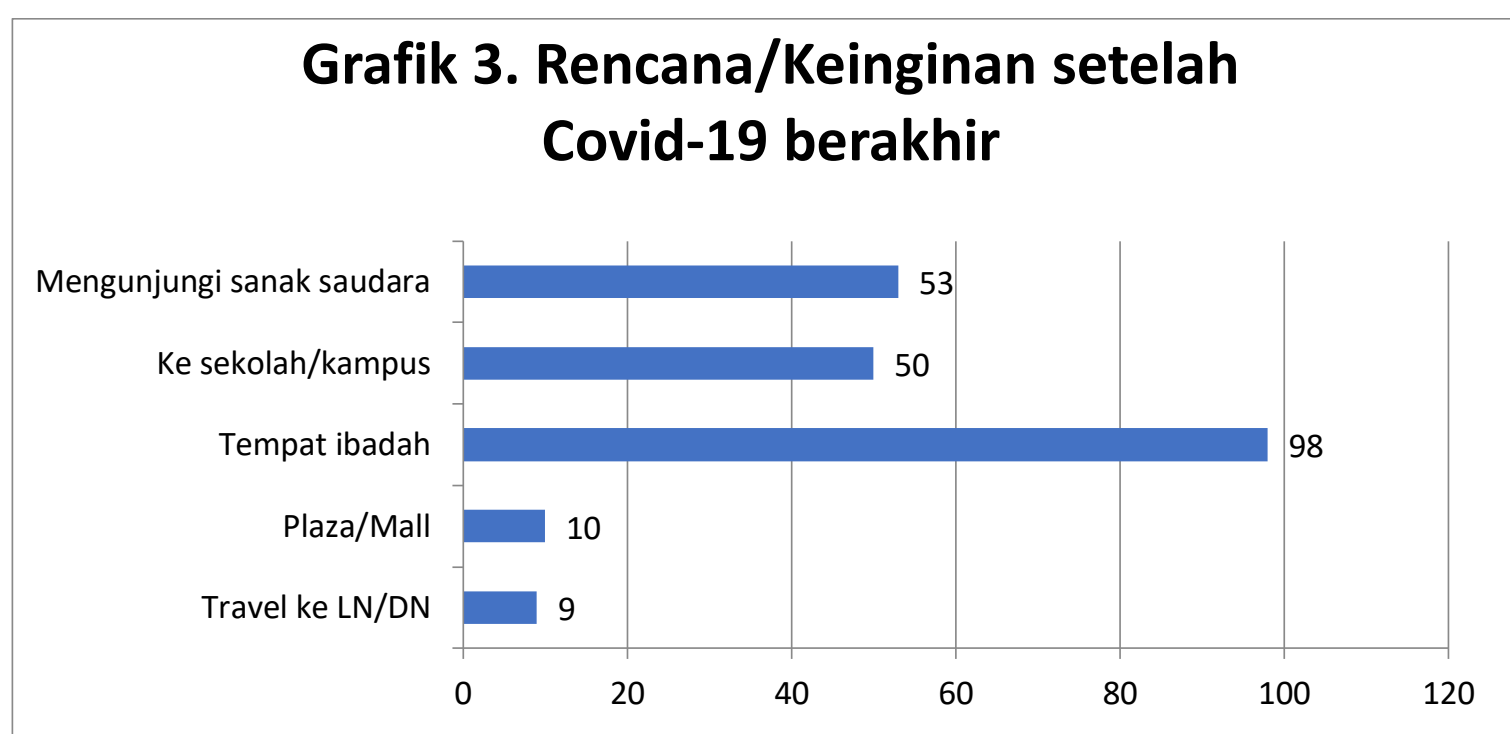

Setiap manusia di dunia ini pastinya sangat berharap pandemic covid-19 segera berakhir. Hal inilah yang menjadi pertimbangan rencana yang akan dilakukan setelah pandemic berakhir. Sebagian besar sebanyak 98 responden menyatakan ketika pandemic berakhir hal pertama yang akan dilakukannya adalah menuju ke tempat ibadah untuk mengucap syukur bahwa pandemic berakhir, dan bisa bertemu dan berkumpul kembali bersama jemaat/umat lainnya. Tampaknya pernyataan ini bisa lahir dikarenakan masih baiknya tingkat religious masyarakat, maka kegembiraan mungkin dirasakan dengan pergi ke tempat ibadah.

Sebanyak 53 responden menyatakan bahwa hal yang akan dilakukan setelah pandemic berakhir adalah mengunjungi sanak saudara yang sempat tertunda karena adanya covid-19. Kebijakan dirumah aja memang memaksa kita terbatas untuk keluar rumah, termasuk mengunjungi sanak keluarga, yang kemungkinan berada diluar daerah. Kemudian kebijakan untuk belajar dari rumah juga membuat mahasiswa/anak sekolah tidak bisa ke sekolah/kampus, oleh karenanya ada 50 responden yang menyatakan aktivitas pertama yang akan dilakukannya adalah pergi belajar di sekolah atau kampus kembali. Responden yang sebagian besar adalah usia mahasiswa mungkin membuat pernyataan ini menjadi cukup tinggi responnya. Sisa respon adalah jalan-jalan ke mall/plaza (10 orang) dan travel ke luar negeri atau dalam negeri (9 orang). Pilihan ini tidak terlalu besar mungkin karena masih ada sisa kekuatiran virus covid-19 masih ada, sehingga lebih baik berjaga-jaga untuk tidak masuk kearea yang ramai seperti mall/plaza ataupun tempat wisata di luar negeri dan dalam negeri. 


\section{Kepercayaan Terhadap Pemerintah Pusat dan Daerah}

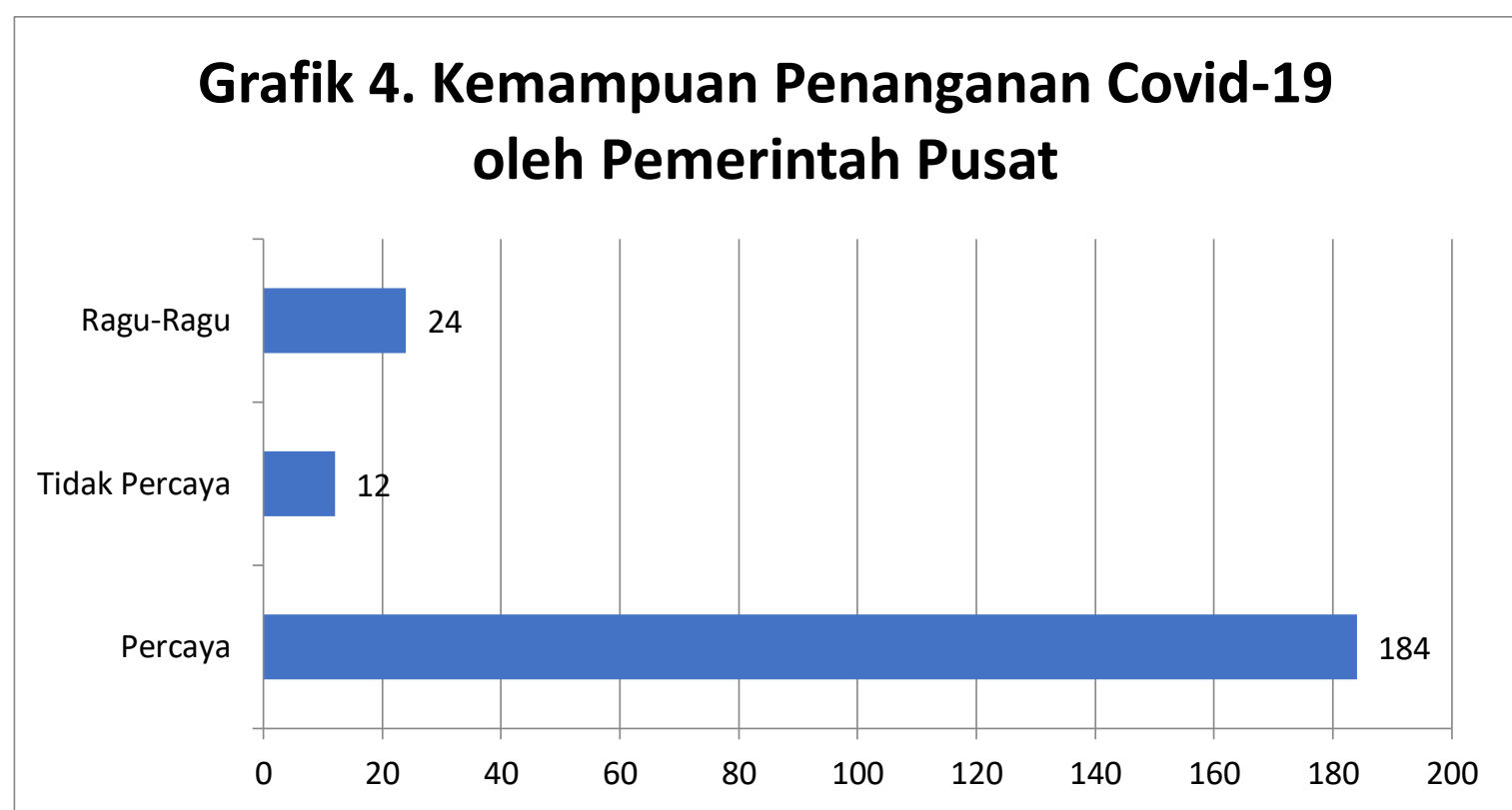

Grafik 4 merujuk tingkat kepercayaan responden terhadap kemampuan pemerintah pusat dalam menanggulangi pandemic Covid-19. Dari 220 orang responden, dominan memilki kepercayaan kepada pemerintah pusat (184 orang), sisanya 24 orang merasakan keraguan, dan 12 responden tidak percaya meyakini ketidakmampuan pemerintah pusat dalam mengatasi pandemic Covid-19.

Dengan demikian, sebagian besar masih merasakan kepercayaan bahwa setiap kebijakan yang dilakukan oleh Pemerintah Pusat untuk menangani pandemic bisa mengatasi penyebaran covid-19. Pemerintah sudah mengeluarkan kebijakan yang diawali dari pembentukan Gugus Kendali Covid-19 dari BNPB, himbauan untuk tinggal dan kerja dari rumah yang kemudian sudah dikembangkan menjadi pembatasan sosial berskala besar (PSBB) yang sudah mulai dijalankan oleh beberapa Pemerintah daerah. Kebijakan ini pada dasarnya memaksa masyarakat untuk tidak banyak melakukan aktivitas diluar rumah, tidak berkerumun, tidak melakukan ibadah di tempat ibadah, dan tidak dulu sekolah dan kuliah. Pemerintah Indonesia sendiri tidak berpangku tangan dalam menyiasati keadaan ini. Beberapa stimulus telah dikeluarkan diantaranya yang terbagi dalam tiga sector, fiscal, non-fiskal, dan ekonomi.

Stimulus fiscal berupa pembebasan pajak bagi empat sector ( $P P h ~ 21,22,25$, dan pajak hotel dan restoran) selama 6 bulan, penyaluran bantuan social, subsidi transportasi, dan bantuan kesehatan bagi paramedic dan korban covid-19. Stimulus non-fiskal diantaranya deregulasi untuk ekspor dan impor barang yang berkaitan dengan ketahanan pangan dan obat-obatan serta penggunaan national logistic system. Sementara stimulus untuk sector ekonomi berupa rekstrukturisasi kredit, relaksasi jaminan social tenaga kerja, penurunan suku bunga. Disamping itu, beberapa program yang langsung bersentuhan dengan masyarakat antara lain, keringanan biaya listrik, keringanan biaya kredit, pengadaan alat kesehatan penunjang, insentif pajak, dan recovery bond untuk melindungi pengusaha. Kebijakan yang nilainya mencapai lebih dari 400 triliun rupiah, meski mungkin tidak secara langsung mencegah dan mengobati akibat penyakit dari covid-19, akan tetapi bisa menjadi berhubungan dengan grafik 2 untuk mengurangi dampak negative yang berpotensi menimbulkan tingkat kekuatiran dan kecemasan karena masalah ekonomi bisa dikurangi. 
Apapun kebijakan yang dikeluarkan oleh Pemerintah pusat jika masyarakat tidak percaya dapat membantu penanganan covid-19 maka kebijakan tersebut sangat mungkin gagal. Jika tidak ada sikap percaya pada Pemerintah maka masyarakat mungkin saja tidak akan mengikuti instruksi pemerintah untuk tinggal dirumah, dan jika itu yang terjadi kita sendiri bisa menyimpulkannya.

\section{Grafik 5. Kemampuan Penanganan Covid-19 oleh Pemerintah Daerah}

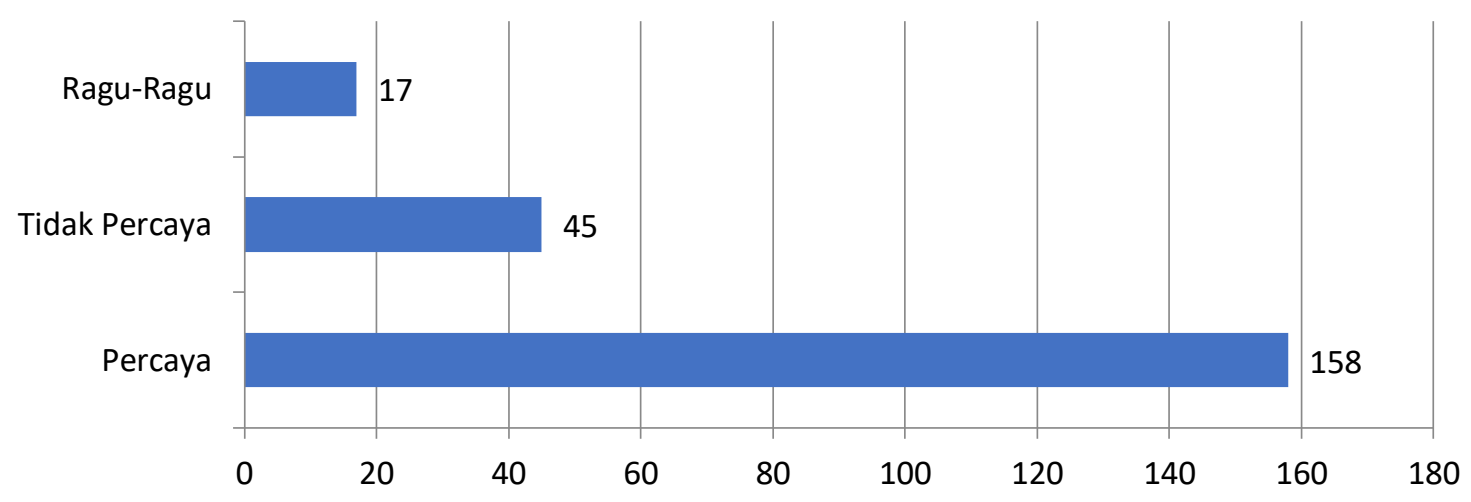

Grafik 5 mendeskripsikan hal yang tidak jauh berbeda hasilnya dengan grafik 4 , mengenai tingkat kepercayaan responden terhadap kemampuan pemerintah daerah, dalam hal ini pemerintah provinsi dan kabupaten/kota untuk mengatasi pandemic Covid-19. Sebanyak 158 responden masih percaya pada pemerintah daerahnya untuk bisa menyelesaikan masalah virus covid-19 ini. Ada 45 responden tidak percaya, dan 17 orang ragu-ragu pada Pemerintah daerah untuk menyelesaikan covid-19.

Di era otonomi daerah saat ini, memungkinkan Pemerintah daera mengeluarkan kebijakannya sendiri sesuai dengan otoritas daerah yang dimilikinya. Terkadang antara Pemerintah pusat dan daerah muncul tidak sinkronnya kebijakan, termasuk kebijakan untuk menangani pandemic covid-19 di Indonesia. Mengacu pada hasil grafik 4 dan 5, dapat dilihat hasil yang relative sama dimana kepercayaan masyarakat masih cukup baik pada pemerintahnya (pusat dan daerah). Bisa saja kita simpulkan bahwa kesamaan hasil tersebut buah dari sinkronisasi kebijakan antara pusat dan daerah terkait situasi darurat nasional covid19. Walaupun mungkin saja masih ada beberapa friksi perbedaan kebijakan dibeberapa daerah (hasil kesimpulan dari berbagai media kredibel) akan tetapi tidak sampai meluas perbedaanya, pemerintah daerah masih tunduk pada regulasi kebijakan terpusat untuk penanganan pandemic covid-19. Gugus tugas penanganan Covid-19 dan Kementerian terkait tampaknya cukup sukses membuat sinkronisasi kebijakan ini. Anggaran Pendapatan Belanja Negara (APBN) dan anggaran belanja daerah (APBD) sudah direvisi kembali untuk semata-mata kepentingan nasional dan daerah.

Pemerintah Sulawesi Utara sendiri telah mengeluarkan kebijakan untuk membantu menanggulangi pandemic covid khususnya di Sulawesi Utara, diantaranya; kebijakan belajar dan kerja dirumah, pemberian bantuan social kepada penduduk rentan terdampak, insentif pajak daerah bagi pelaku usaha dan operator moda transportasi darat. Kebijakan apapun yang dikeluarkan memang tidak bisa sempurna dan menyenangkan seluruh masyarakat, akan tetapi yang dibutuhkan Pemerintah pusat dan daerah masyarakat bisa percaya pada pemerintah akan berbuat semaksimal mungkin untuk mengurangi dampak buruk dari covid-19, baik yang berkaitan dari sisi kesehatan dan ekonomi. 

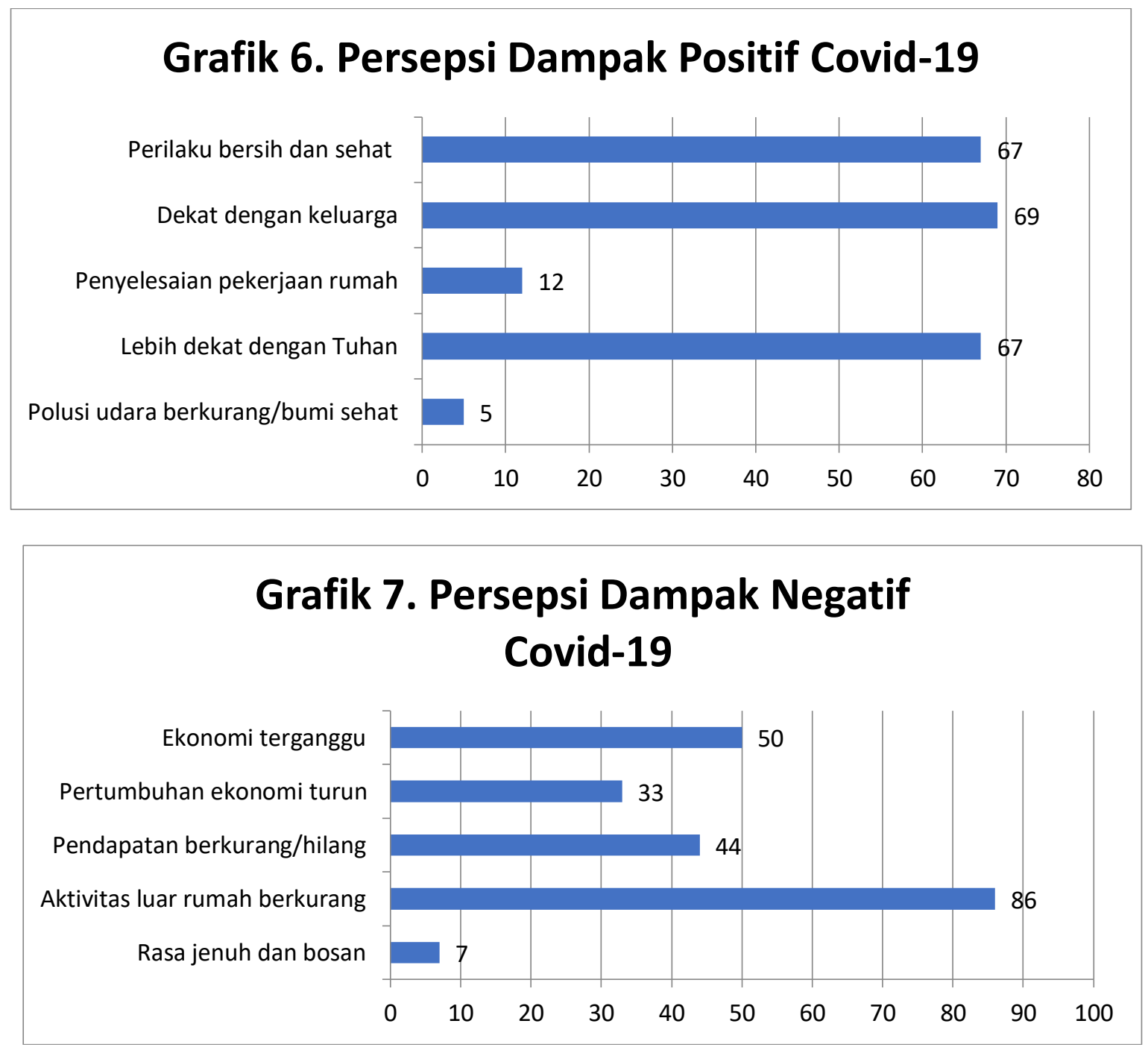

Apapun yang terjadi pada diri manusia biasanya melahirkan dampak positif ataupun negative pada diri manusia, baik yang berdampak secara langsung atau tidak langsung pada dirinya. Dipercaya bahwa pandemic covid-19 inipun mempunyai 2 sisi tersebut. Pada grafik 6 dan 7 ditunjukkan persepsi 220 responden terhadap dampak positif dan dampak negative yang dirasakan. Pada bagian ini kuesioner yang dikirimkan secara online tidak berupa pilihan jawaban yang bisa dipilih oleh responden, dibagian ini responden dibebaskan memberi jawaban tentang apa yang dirasakan oleh responden. Setelah dijawab setiap pernyataan dikelompokkan dari setiap item yang dituliskan oleh responden. Kelompok pernyataan dampak positif adalah peningkatan perilaku hidup bersih dan sehat, kedekatan hubungan keluarga, pekerjaan rumah yang tertunda terselesaikan, kdekatan hubungan dengan Tuhan, dan polusi udara berkurang. Sedangkan pada pernyataan dampak negative dikelompokkan, ekonomi secara umum terganggu, pendapatan berkurang, pertumbuhan ekonomi turun, aktivitas luar rumah berkurang, dan rasa jenuh serta bosan.

Pada sisi positif covid-19 (lihat grafik 6) perliku hidup bersih dan sehat, kedekatan dengan keluarga, dan kedekatan dengan Tuhan memiliki porsi terbesar, setiap item pernyataan dipilih diangka 67 untuk perilaku hidup bersih dan sehat, dan kedekatan dengan Tuhan. Angka 
69 untuk kedekatan dengan keluarga. Porsi kecil jawaban ada di penyelesaian pekerjaan rumah yang tertunda (12 respnden) dan berkurangnya polusi udara yaitu 7 responden. Dengan mengacu pada grafik 5 tersebut dapat disimpulkan adanya pandemic covid-19 yang tadinya mungkin tidak memperdulikan kebersihan dan kesehatan tubuhnya sekarang menjadi lebih peduli. Pola hidup yang lebih bersih dan sehat dimasyarakat diakui lebih baik dari sebelumnya. Anjuran pemerintah untuk selalu menjaga imunitas tubuh, ditanggapi masyaraka secara umum dengan memperbanyak makan-makanan yang lebih sehat dan dimasak dengan lebih baik dari sebelumnya. Anjuran bahkan menjurus ke instruksi pemerintah untuk selalu cuci tangan dengan sabun, membuat masyarakat menjadi sangat sering cuci tangan setiap kali beraktivitas dan memegang benda-benda kotor ataupun yang kelihatannya bersih. Saat ini banyak ditemui ditengah masyarakat dan dijalan-jalan umum tempat cuci tangan lengkap dengan sabun, baik yang disediakan oleh Pemerintah dan swadaya masyarakat itu sendiri.

Sebelumnya masyarakat secara umum lebih sibuk bekerja, sehingga kuantitas dan mungkin kualitas waktu dengan keluarga kurang, maka dengan kebijakan dirumah saja, kerja dan sekolah dari rumah kualitas dan kuantitas waktu dengan keluarga semakin banyak. Di Kota besar seperti Jakarta, banyak ditemui orangtua berangkat kerja jam 5 pagi anak masih tidur, pulang kerja jam 9 malam anak sudah tidur, sehingga sering ditemui anak menjadi lebih dekat dengan pengasuhnya daripada orangtuannya sendiri. Dengan adanya pandemic ini dinding pemisah antara orangtua dan anak serta keluarga lainnya yang satu rumah seakan runtuh. Anakanak bisa menjadi dekat dengan orangtuannya, banyak waktu sekolah dan bermain bersama orang tuanya. Dipercayai saat ini banyak anak-anak banyak bersyukur dengan keadaan pandemic ini. Saat ini istilah yang jauh didekatkan yang dekat dijauhkan tampaknya berlaku. Dulu jauh dari orangtua sekarang dekat dengan keluarga, yang dulu dekat dengan pekerjaannya sekarang dijauhkan pekerjaannya.

Selain itu dengan adanya pandemic ini, tampaknya tingkat keimanan masyarakat menjadi lebih baik. Hal ini menjadi menarik, saat sebagian orang protes larangan ibadah di tempat ibadah dikutirkan akan menghilangkan persektuan jemaat/umat dengan Tuhan, tetapi ditengah masyarakat kedekatan dengan Tuhan menjadi salah satu pilihan sisi positif dari covid19 ini. Beribadah dari rumah mungkin tidak menjadi hal yang perlu dikuatirkan akan melemahkan iman seseorang dengan berkurangnya persekutuan jemaat/umat di tempat ibadah karena tampaknya iman bisa lebih meningkat. Di awal bulan Maret 2020, ada seruan dari Pemerintah Sulawesi Utara untuk tepat jam 12.00 bersama-sama secara serempak untuk berdoa bersama untuk keselamatan Sulawesi Utara. Dipercayai oleh Pemerintah, seruan itu sangat sukses.

Harus diakui banyak jemaat saat jam ibadah pada situasi normal, tidak lagi terlau focus ibadah ditempat ibadah. Hasil pengamatan, dibeberapa gereja di Sulawesi Utara saat jam ibadah, banyak jemaat ada diluar gereja atau duduk dibelakang asik bermain ponsel pintarnya dan menghisap rokok. Bagi seluruh umat beragama, dipercayai bahwa Tuhan itu tidak ingin dinomor duakan, Dia ingin menjadi nomor satu dalam hati dan pikiran manusia. Mungkin saja pandemic covid-19 Tuhan sedang menyatakan diri-Nya bahwa dia maha kuasa, mampu membuat yang dulu tidak ada menjadi ada, yang saat ini ada menjadi tidak ada. Dirumah saja, mungkin membuat manusia lebih sadar akan hal itu, dan justru memperbanyak aktivitas berdoanya. Sebagai contoh, umat muslim dengan sholat 5 waktunya, mungkin saja saat ini bukan hanya 5 waktu, tetapi 6 waktu, 7 waktu, 8 waktu dan seterusnya, lebih banyak waktu berhubungan dengan Tuhan dengan doa. Bagi umat lainnya seperti Kristiani, aktivitas doa bisa lebih banyak dipraktikkan saat bangun tidur pagi, saat makan, saat tidur malam dan banyak saat-saat lainnya yang mungkin pada situasi normal banyak terlupakan. 
Pada grafik 7 ditunjukkan dampak negative yang dirasakan oleh masyarakat. Dari 5 hal yang dirasakan sebagai dampak negative, 3 hal berkaitan dengan ekonomi dan 2 hal berkitan dengan aktivitas pembatasan jarak dan sosial secara langsung dimasyarakat. Hal yang paling dirasakan menjadi hal negative akibat pandemic covid-19 adalah ekonomi yang terganggu, pendapatan yang menurun/hilang dan pertumbuhan minus ekonomi, total responden yang menyatakannya adalah 127 responden. Sedangkan masalah sosial seperti kurangnya waktu beraktivitas diluar, seperti ke kampus, sekolah, ibdah di tempat ibadah dan pertemuanpertemuan lainnya ada cukup banyak, yaitu sebanyak 86 responden. Jika ditambah dengan rasa jenuh dan bosan total menjadi 93 responden. Dengan kata lain dampak negative secara garis besar yang dirasakan masyarakat adalah masalah ekonomi dan masalah hubungan sosial.

Masalah kesehatan dari pandemic covid-19 ini secara umum memang banyak mengganggu aktivitas ekonomi nasional dan global. Bisnis pariwisata dengan bisnis turunannya seperti hotel, UMKM di penjualan cenderamata, pemandu wisata, sewa kendaraan dll menjadi sangat terpukul. Dibanyak pemberitaan media televisi (Kompas TV, CNN Indonesia) berulang kali diberitakan bahwa tingkat okupansi hotel hanya $10 \%$ saja. Padahal tingkat okupansi minimal agar bisa membiayai operasional adalah $60-70 \%$, akibatnya banyak pegawai terpaksa dirumahkan bahkan di PHK. Di Sulawesi Utarapun demikian, hotel-hotel di Sulawesi Utara yang biasanya penuh dengan turis dari tiongkok kini menjadi kosong tingkat huniannya. Data BPS Provinsi Sulut tahun 2020 menjelaskan pada periode Januari s/d Maret 2020 penurunan pariwisat menurun tajam dibandingkan periode yang sama di tahun 2019 . Pertokoan dan pusat pembelanjaan di Kota Manado ditutup dan terus diperpanjang. Rumah makan hanya melayani pesan antar saja. Sekolah dan kampus yang tutup misalnya berimbas pada tutupnya kantin yang biasanya ramai dengan mahasiswa dan anak sekolah. Kos-kos sekitar kampus juga menjadi kosong karena sebagian besar penyewanya sudah mulai pulang ke kampung halamannya. Salah satu pemilik kos di area kampus Universitas Negeri Manado di Tondano menjelaskan bahwa mahasiswa yang masih tinggal di kos adalah mahasiswa yang berasal dari luar Sulawesi Utara dan kesulitan dalam ekonominya.

Masalah sosial seperti kurangnya aktivitas diluar rumah yang biasanya sering dilakukan menjadi tiba-tiba tidak bisa dilaksanakan. Larangan ibadah di tempat ibadah dan dirumahrumah memaksa tidak bisa dilakukan lagi untuk sementara waktu, salah satu pemuka agama di salah satu gereja di Kota Tomohon menjelaskan bahwa kami hanya mengikuti kebijakan organisasi pusat gereja dan pemerintah saja, jika bisa memilih kami berharap pelaksanaan ibadah tetap dilaksanakan dengan jaga jarak. Biasanya mahasiswa/anak sekolah disibukkan dengan perkualiahan tiap harinya dan bisa bertemu dan bercengkrama dengan teman-temanya, kini tidak bisa dilakukan kembali. Maka tidak mengherankan sebagian responden mengatakan bahwa rasa jenuh dan bosan sudah dirasakannya.

\section{Kesimpulan}

Dari hasil 220 data dan informasi yang bisa diperoleh dari hasil survey ini dapat dijelaskan bahwa pandemic covid-19 di Indonesia menyebabkan beberapa perilaku yang berubah. Diawali dari aktivitas panic buyingmeksipun angkanya tidak terlalu besar, tetapi pandemic ini membuat kecemasan dan kekhawatiran akan ketidakpastian menunjukkan perasaan masyarakat yang sesungguhnya (grafik 1 \& 2). Data dari 220 responden juga menunjukkan hal yang positif dari tingkat optimisme masih dirasakan. Kerinduan melanjutkan aktivitas rutin seperti menjalankan ibadah, mengunjungi saudara/kerabat, dan bekerja/kuliah/sekolah (grafik 3) menunjukkan mereka percaya diri dan memiliki pengharapan positif pandemic ini akan berlalu. 
Kepercayaan responden terhadap pemerintah, baik pemerintah pusat (grafik 4) maupun pemerintah daerah (grafik 5) dalam menyelesaikan pandemic juga cukup tinggi, walaupun tidak bisa disimpulkan bahwa ini adalah pandangan umum masyarakat, akan tetapi data yang dihasilkan menunjukkan sesuatu hal yang optimis. Demikian juga dengan sikap dan persepsi responden dimana keberadaan pandemi telah memberikan positif, mereka mulai terbiasa dengan hidup sehat, lebih religious, dan memiliki waktu lebih banyak dengan keluarga (grafik 6). Disisi lain, pandemi telah mengganggu ekonomi keluarga dan aktivitas luar rumah yang biasanya rutin seperti bekerja/kuliah, belanja, nongkrong, dan lainnya (grafik 7). Kejadian force majeur seperti ini sedikit banyak telah mengubah pola hidup masyarakat menjadi lebih awas dan waspada namun tetap optimis menatap hari esok.

\section{Implikasi Manajerial}

Temuan dalam penelitian bisa menjadi suatu pijakan perlunya national logistic system sebagai antisipasi kejadian force majeur seperti pandemi, bencana alam, dan lainnya sehingga panic buying atau consumer hoarding tidak akan mengganggu ketersediaan barang dipasar yang menyebabkan kelangkaan dan kenaikan harga. Kecemasan dan kekhawatiran sebagai awal terbentuknya persepsi masyarakat akan menjadi lebih mudah dikontrol jika media social ikut mendukung opini positif bagi mereka. Kehadiran Negara dan pemerintah sebagai penyelenggara ikut mendukung optimisme masyarakat sehingga persepsi masyarakat yang membentuk optimism semakin tinggi.

\section{Keterbatasan dan Saran}

Riset ini memiliki keterbatasan, penelitian dengan statistic deskriptif ini tidak bisa menjadikan hasil riset dapat disimpulkan secara umum. Riset ini hanya bisa menjangkau sebanyak 220 responden dalam riset. Dengan kata lain fenomena yang dijelaskan hanya terbatas pada realita pada 220 responden tersebut. Untuk menutupi kelemahannya kombinasi pengumpulan data dengan wawancara via media social whatsapp coba dilakukan, akan tetapi tetap tidak bisa menjadikan riset ini dapat digunakan sebagai bentuk prediksi secara umum. Walaupun demikian, hasil riset bisa menjadi lebih baik dikarenakan bisa memberikan penjelasan kualitatif yang diperlukan.

Penelitian ini, sesungguhnya banyak hal yang belum dapat dijangkau dan ditemukan. Namun sebagai pijakan untuk penelitian berikutnya, ada baiknya sisi psikologis masyarakat dan pengambil keputusan ikut dipelajari. Pembentukan persepsi dari sisi kecemasan dan kekhawatiran serta optimisme masyarakat dapat ditelaah dalam penelitian ini, namun belum menyentuh penyelenggara negara (pemerintah pusat dan daerah) sebagai stakeholder. Hal ini sebagai bukti komparasi mengenai apa yang diharapkan penyelenggara atas suatu keputusan dan respon dari masyarakat mengenai keputusan itu sendiri dapat terbuka.

Selain itu, sehubungan dengan kejadian force majeur, seperti pandemic dan bencana alam lainnya, sebaiknya ikut diamati budaya, norma, nilai, dan kepercayaan yang dianut oleh masyarakat sekitar dalam beradaptasi dengan perubahan aturan pemerintah. Hal ini penting untuk diamati seberapa cepat kemampuan masyarakat dalam beradaptasi dengan perubahan. Pengamatan ini akan semakin lengkap jika studi lintas budaya ikut menjadi titik penting. 
INOBIS: Jurnal Inovasi Bisnis dan Manajemen Indonesia Volume 04, Nomor 01, Desember 2020

Nikolas F. Wuryaningrat, Aditya Pandowo, Lydia I. Kumajas

\section{Daftar Pustaka}

Allison, T., Puce, A., \& McCarthy, G. (2000). Social perception from visual cues: role of the STS region. Trends in Cognitive Sciences, 4(7), 267-278. https://doi.org/10.1016/S1364-6613(00)01501-1

Baron, R. A., \& Branscombe, N. R. (2012). Social Psychology (13th ed.). Pearson Education.

Craven, M., Liu, L., Mysore, M., dan Wilson, M., 2020.COVID-19: Implicationsfor business, McKinsey and Company.

Fang, Y., \& Shou, B. (2015). Managing supply uncertainty under supply chain Cournot competition. European Journal of Operational Research, 243(1), 156-176. https://doi.org/https://doi.org/10.1016/j.ejor.2014.11.038

Hanurawan, F. (2007). Pengantar psikologi sosial. Universitas Negeri Malang.

Kaplan, B. J., Crawford, S. G., Field, C. J., \& Simpson, J. S. A. (2007). Vitamins, Minerals, and Mood. Psychological Bulletin, 133(5), 747-760. https://doi.org/10.1037/00332909.133.5.747

Knoblich, G., \& Prinz, W. (2001). Recognition of self-generated actions from kinematic displays of drawing. Journal of Experimental Psychology: Human Perception and Performance, 27, 456-465. https://doi.org/10.1037/0096-1523.27.2.456

Kumar, M., Basu, P., \& Avittathur, B. (2018). Pricing and sourcing strategies for competing retailers in supply chains under disruption risk. European Journal of Operational Research, 265(2), 533-543. https://doi.org/10.1016/j.ejor.2017.08.019

Passer, M. W., \& Smith, R. E. (2009). Psychology: The science of mind and behaviour (4th ed., Vol. 39, Issue 8). McGraw-Hill. https://doi.org/10.1037/034611

Turambi, R. D., \& Wuryaningrat, N. F. (2020). Panic buying perception in Walian Satu SubDistrict, Tomohon City. International Journal of Applied Business and International Management-Student Edition, August, 1-7.

Wuryaningrat, N.F., Kawulur, A.F., \& Kumajas, L.I. 2017. Examining An Endangered Knowledge Transfer Practice Known As "Mapalus" In An Indonesian Village: Implications For Entrepreneurial Activities And Economic Development. International Journal Business and Society, 18(S2), 309-322. 